\title{
HUBUNGAN MUTU GURU, KEPEMIMPINAN KEPALA SEKOLAH, DAN STATUS EKONOMI GURU DENGAN KINERJA GURU SD KECAMATAN SURALAGA LOMBOK TIMUR
}

\section{THE RELATIONSHIP BETWEEN TEACHERS' QUALITY, PRINCIPALS' LEADERSHIP', AND TEACHERS' ECONOMIC STATUS AND PERFORMANCE OF THE TEACHERS OF ELEMENTARY SCHOOLS IN SURALAGA DISTRICT OF EAST LOMBOK.}

\author{
Muh. Yazid, Cepi Safruddin Abdul Jabar \\ PPs UNY, Universitas Negeri Yogyakarta \\ yazidmuhammad775@yahoo.co.id, cepi_safruddin@uny.ac.id
}

\begin{abstract}
Abstrak
Penelitian ini bertujuan untuk mengetahui hubungan antara mutu guru dengan kinerja guru, hubungan kepemimpinan kepala sekolah dengan kinerja guru, hubungan status ekonomi (SE) guru dengan kinerja guru, dan hubungan bersama-sama antara mutu guru, kepemimpinan kepala sekolah, dan SE guru dengan kinerja guru di Kecamatan Suralaga, Kabupaten Lombok Timur. Penelitian ini menggunakan pendekatan korelasional. Hasil analisis menunjukkan bahwa: (1) ada hubungan yang positif dan signifikan antara mutu guru dengan kinerja guru, nilai koefisien $r$ sebesar 0.446 , koefisien $\mathrm{r}^{2}$ sebesar 0.199, besar sumbangan sebesar $19.9 \%$ dan p (signifikan) sebesar 0.000; (2) ada hubungan yang positif dan signifikan antara kepemimpinan kepala sekolah dengan kinerja guru, nilai koefisien $\mathrm{R}$ sebesar 0.569 , koefisien $\mathrm{R}^{2}$ sebesar 0.323 , besar sumbangan $32.3 \%$ dan $\mathrm{p}$ (signifikan) sebesar 0.006; (3) ada hubungan yang positif dan signifikan antara SE dengan kinerja guru, nilai koefisien $r$ sebesar 0.214 sedangkan koefisien $\mathrm{R}^{2}$ sebesar 0.046 ; besar sumbangan $4.6 \%$ dan nilai $\mathrm{p}$ (signifikan) sebesar 0.014; (4) ada hubungan positif dan signifikan antara mutu guru, kepemimpinan kepala sekolah dan SE dengan kinerja guru, nilai korelasi R sebesar 0.769 , koefisien $\mathrm{r}^{2}$ sebesar 0.591 , besar sumbangan $59.1 \%$ dan nilai signifikan sebesar 0.001 ,
\end{abstract}

Kata Kunci : mutu, kepemimpinan, SE, dan kinerja

\begin{abstract}
This study aims to determine the relationship between teachers' quality and teachers' performance, principals' leadership and teachers' performance; the relationship between teachers' ES and teachers' performance; and the relationship between teachers quality, principals' leadership and teachers' ES and the performance of the teachers in Suralaga District of East Lombok. This study used the correlation approach. The result of the analysis shows that: (1) there is a positive and significant relationship between the teachers performance and the teachers' quality with the value of $R$ coefficient being 0.446, $R^{2}$ coefficient being 0.199, major contribution being $19.9 \%$ and $p$ (significant) being 0.000; (2) there is a positive and significant relationship between the principals' leadership and teachers performance with the value of coefficient $R$ being $0.569, R^{2}$ coefficient being 0.323 , major contribution being $32.3 \%$ and $p$ (significant) being 0.006 ; (3) there is a positive and significant relationship between teachers' ES and the performance of teachers with the value of coefficient $R$ being 0.214 and the $R^{2}$ coefficient being 0.046, major contribution being $4.6 \%$ and the value of $p$ (significant) being $0.014 ;$ (4) there is a positive and significant correlation between the teachers' quality, principals' leadership and teachers' ES and the teachers' performance with the correlation value $R$ being 0.769, $R^{2}$ coefficient being 0.591, the contribution being $59.1 \%$ and a significant value being 0.001,
\end{abstract}

Keywords: quality, leadership, SE, and performance. 


\section{Pendahuluan}

Guru adalah ujung tombak bagi pendidikan, keberhasilan pendidikan tidak terlepas dari peran pendidik yang handal. Sebagaimana yang di ungkapkan oleh (Rivai dan Murni, 2012, p.896) yang mengatakan bahwa guru memegang peranan sentral dalam proses belajar mengajar, untuk itu mutu pendidikan di suatu sekolah sangat ditentukan oleh kemampuan yang dimiliki seorang guru dalam menjalankan tugasnya.

Mengingat akan penting/beratnya tugas dan tanggung jawab seorang pendidik/guru yaitu mempersiapkan generasi muda dengan ilmu pengetahuan, maka yang harus diperhatikan bagi setiap guru adalah kualifikasi pendidikan. Yang dimaksud dengan kualifikasi pendidikan sebagaimana yang dimuat dalam UU No. 14 tahun 2005 tentang Undang-Undang Guru dan Dosen dalam pasal 8 adalah "Guru wajib memiliki kualifikasi akademik, kompetensi, sertifikat pendidik, sehat jasmani dan rohani serta memiliki kemampuan untuk mewujudkan tujuan Pendidikan Nasional". Adapun yang dimaksud dengan kualifikasi akademik pada pasal di atas adalah guru harus memiliki sertifikat pengajar/ijazah kesarjanaan sebagaimana dijelaskan dalam UU No. 14 tahun 2005 tentang Undang-Undang Guru dan Dosen dalam pasal 9 adalah "kualifikasi akademik sebagaimana yang dimaksud dalam pasal 8 di peroleh melalui pendidikan tinggi program Sarjana (S-1) atau Program Diploma Empat (D-IV)".

Dari data yang diperoleh dari Dinas Pendidikan Pemuda dan Olahraga Kabupaten Lombok Timur, guru yang belum memiliki kualifikasi akademik yang mengajar di SD dan MI se-Lombok Timur masih cukup tinggi, dari 10.234 orang guru, yang belum memiliki kualifikasi akademik sekitar 6.249 atau $61.42 \%$.

Tabel 1. Kualifikasi Guru di Kabupaten Lombok Timur Berdasarkan Kualifikasi Akademik yang Mengajar pada SD dan MI

\begin{tabular}{llcc}
\hline No & $\begin{array}{c}\text { Kualifikasi } \\
\text { Akademik }\end{array}$ & Jumlah & $\begin{array}{c}\text { Presentase } \\
(\%)\end{array}$ \\
\hline 1 & SLTA & 1649 & $16,11 \%$ \\
2 & Diploma I/ D-1 & 18 & $0,17 \%$ \\
3 & Diploma II/ D-2 & 4364 & $42,64 \%$ \\
4 & Diploma III/D-3 & 218 & $2,13 \%$ \\
5 & Strata 1/ S-1 & 3929 & $38,39 \%$ \\
6 & Strata 2/ S-2 & 56 & $0,54 \%$ \\
\hline
\end{tabular}

Sumber : Dinas Pendidikan Pemuda dan Olahraga Lombok Timur Tahun 2012
Dari data yang diperoleh dari Dinas Pendidikan Pemuda dan Olahraga Kabupaten Lombok Timur, guru yang belum memiliki kualifikasi akademik yang mengajar di SD dan MI se-Lombok Timur masih cukup tinggi, dari 10.234 orang guru, yang belum memiliki kualifikasi akademik sekitar 6.249 atau $61.42 \%$.

Mutu guru adalah guru yang memiliki kualifikasi akademik sesuai kriteria yang berlaku, kompetensi yang memadai, menguasai materi ajar yang sesuai dengan standar isi, melaksanakan proses pembelajaran yang sesuai dengan standar proses dan memiliki sertifikasi pendidik yang dikeluarkan oleh penyelenggara.

Dalam Undang-Undang No. 14 Tahun 2005 tentang Guru dan Dosen pasal 10 ayat 1 menyatakan bahwa "Kompetensi guru sebagaimana yang dimaksudkan dalam pasal 8 meliputi kompetensi pedagogik, kompetensi kepribadian, kompetensi sosial dan kompetensi profesional yang diperoleh melalui pendidikan profesi".

Sertifikasi adalah proses pemberian sertifikat untuk guru. D. Sudjana (2006, p.16) mengemukakan sertifikasi adalah tanda pencapaian kompetensi akhir pendidik dinyatakan dalam dokumen ijazah dan atau sertifikat kompetensi. Sedangkan sertifikat pendidik adalah bukti formal sebagai pengakuan yang diberikan kepada guru sebagai tenaga profesional, maka sertifikat pendidik diberikan kepada guru yang memenuhi persyaratan (Harsono \& Joko Susilo, 2010, p.27).

Tabel 2. Data Sertifikasi Guru di Kabupaten Lombok Timur

\begin{tabular}{ccc}
\hline \multirow{2}{*}{ Guru } & \multicolumn{2}{c}{ Yang Memiliki Sertifikat } \\
\cline { 2 - 3 } & Belum & Sudah \\
\hline SD & 4285 & 2962 \\
MI & 1010 & 1977 \\
$\%$ & $51.74 \%$ & $48.26 \%$ \\
\hline
\end{tabular}

Sumber : Dinas Pendidikan Pemuda dan Olahraga Lombok Timur Tahun 2012

Data di atas menunjukan bahwa guru di Kabupaten Lombok Timur yang belum memiliki sertifikasi masih cukup tinggi, dari seluruh guru yang ada. Guru yang sudah memiliki sertifikasi yaitu $48.26 \%$ sedangkan yang belum bersertifikasi sebanyak $51.74 \%$.

Keberhasilan pendidikan dalam hal ini adalah kinerja guru tidak hanya didukung oleh guru yang bermutu, akan tetapi keberhasilan tersebut tidak terlepas dari peran pemimpin yang mengatur guru di Sekolah/Madrasah. Pemimpin adalah orang yang menggerakkan/ 
mengkoordinir suatu instansi atau lembaga. Sedangkan pemimpin menurut para ahli, pemimpin adalah orang yang mempunyai kemampuan untuk mempengaruhi perilaku orang lain di dalam kerjanya dengan menggunakan kekuasaan (Asmani, 2009, p.92).

Faktor yang berhubungan dengan kinerja guru adalah kemampuan yang mereka miliki, dan terintegrasi oleh tingkat pendidikan mereka. Dan faktor lain yang berhubungan dengan kinerja guru adalah kompetensi (kemampuan) serta penghargaan dan kesejahteraan guru. Ada hubungan yang sangat erat antara kinerja guru dan apresiasi dari banyak kalangan serta kesejahteraan guru/besarnya gaji.

Di Kabupaten Lombok Timur, kepemimpinan kepala sekolah masih banyak di emban oleh pemimpin yang tidak memiliki latar belakang kepemimpinan atau keguruan sehingga kinerja kepala sekolah kurang memuaskan, ini dilihat dari masih banyaknya guru yang belum memiliki kualifikasi akademik S1, juga sertifikasi guru di Kabupaten Lombok Timur masih rendah dikarenakan kepedulian kepala sekolah pada bawahannya masih kurang. Selain itu, masih banyak guru yang mengajar yang bukan pada bidangnya disebabkan oleh kurangnya profesional kepala sekolah dalam menempatkan guru.

Selain mutu guru dan kepemimpinan kepala sekolah, hal yang tidak bisa dilupakan dan diabaikan dalam mempengaruhi kinerja guru adalah status ekonomi (SE) guru, hal ini menjadi tolak ukur sekaligus menjadi indikator bagi instansi yang terkait untuk melihat guru dalam berkarya.

Di Kabupaten Lombok Timur ekonomi guru rata-rata masih rendah. Dalam memenuhi kebutuhan keluarga, masih banyak guru yang bekerja di jam pelajaran berlangsung dikarenakan kesejahteraan guru masih kurang, gaji guru masih jauh dari upah minimum, tunjangan guru juga masih sedikit yaitu 250 ribu per bulan. Hal inilah yang mendorong para guru untuk mencari kerja sampingan demi untuk memenuhi ekonomi keluarga.

Hasil penelitian yang dilakukan oleh Basilius Redan Wereng (2010): Pengaruh Keterampilan Manajerial Kepala Sekolah dan Status Sosial Ekonomi Guru terhadap Kinerja Guru SMA Negeri I Merauke-Papua. Hasil penelitian menunjukan bahwa: (1) Keterampilan Manajerial Kepala Sekolah memiliki pengaruh yang signifikan terhadap kinerja guru SMA Negeri I Merauke-Papua berdasarkan ha- sil analisis data diperoleh nilai koefisien beta ( $\beta$ ) 0,618 dengan taraf signifikan sebesar 0,05 ; (2) Status Sosial Ekonomi memiliki pengaruh yang signifikan terhadap kinerja guru SMA Negeri I Merauke-Papua hasil analisis data diperoleh nilai koefisien beta $(\beta)-0,273$ dengan taraf signifikan sebesar 0,05; (3) Keterampilan Manajerial Kepala Sekolah dan Status Sosial Ekonomi secara bersama-sama memiliki pengaruh yang signifikan terhadap kinerja guru SMA Negeri I Merauke-Papua berdasarkan analisis data diperoleh sumbangan efektif sebesar $69 \%$.

Penelitian ini bertujuan untuk mengetahui hubungan variabel-variabel bebas (mutu guru, kepemimpinan kepala sekolah, dan status ekonomi guru) dengan variabel terikat (kinerja guru) di Kecamatan Suralaga, Kabupaten Lombok Timur.

\section{Metode}

Jenis penelitian ini adalah penelitian korelasional, karena dalam penelitian ini ingin mengetahui hubungan variabel-variabel bebas mutu guru $\left(\mathrm{X}_{1}\right)$, kepemimpinan kepala sekolah $\left(\mathrm{X}_{2}\right)$, SE guru $\left(\mathrm{X}_{3}\right)$ dengan variabel terikat kinerja guru (Y). Keterkaitan antara variabel mutu guru, kepemimpinan kepala sekolah dan SE dalam penelitian ini digambarkan dalam bagan berikut :

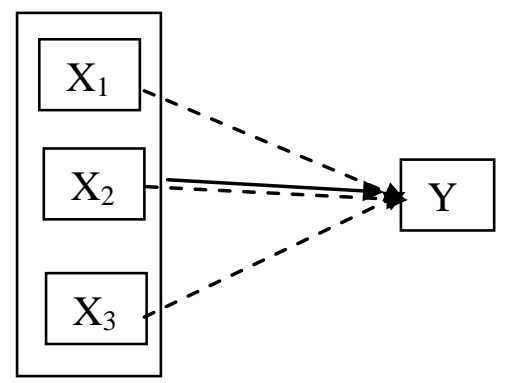

Gambar 1. Desain Penelitian

Penelitian ini dilaksanakan di Sekolah Dasar (SD/MI) Kecamatan Suralaga Kabupaten Lombok Timur. Waktu penelitian dilaksanakan pada bulan September sampai Maret 2013.

Populasi dalam penelitian ini adalah seluruh kepala sekolah dasar (SD/MI) dan guru sekolah dasar (SD/MI) yang ada di Kecamatan Suralaga Kabupaten Lombok Timur. Dengan rincian 30 sekolah dasar dan 17 Madrasah Ibtidaiah dengan banyak populasi adalah 581 orang: 
Tabel 3. Keadaan Populasi Penelitian

\begin{tabular}{lcc}
\hline \multicolumn{1}{c}{ Populasi } & Banyak & Jumlah \\
\hline Guru MI & 225 & \\
Guru SD & 309 & 581 \\
Kepala Sekolah SD \& MI & 47 & \\
\hline
\end{tabular}

Sumber Data : UPTD Kecamatan Suralaga 2012

Sedangkan sampel dalam penelitian ini sebanyak 154 yang terdiri dari 22 kepala sekolah dan 132 guru (guru kelas). Teknik penarikan sampel adalah teknik acak sampling.

Tabel 4. Keadaan Sampel Penelitian

\begin{tabular}{lcc}
\hline \multicolumn{1}{c}{ Sampel } & Banyak & Jumlah \\
\hline Guru MI & 48 & \\
Guru SD & 84 & 154 \\
Kepala Sekolah SD \& MI & 22 & \\
\hline
\end{tabular}

Teknik pengumpulan data dalam penelitian ini adalah survei dengan menggunakan alat pengumpul data berupa angket penelitian. Pengumpulan data tentang mutu guru, kepemimpinan kepala sekolah dan SE, diperoleh dengan membagikan instrumen/angket pada responden, pada pengambilan data responden tinggal mengisi lembar pengumpul data sesuai dengan petunjuk yang diberikan dan memberikan kesempatan kepada responden untuk menanyakan hal-hal yang belum dipahami.

Jenis angket yang digunakan untuk mendapatkan data dari variabel mutu guru $\left(\mathrm{X}_{1}\right)$, kepemimpinan kepala sekolah $\left(\mathrm{X}_{2}\right)$, SE guru $\left(\mathrm{X}_{3}\right)$, dan kinerja guru $(\mathrm{Y})$ adalah angket tertutup.

Penelitian ini merupakan penelitian kuantitatif yang menggunakan statistik. Data akan dianalisis dengan statistik deskriptif dan inferensial. Statistik deskriptif akan menggambarkan data yang telah terkumpul sebagaimana adanya. sedangkan statistik inferensial pada penelitian ini dilakukan dengan menganalisis data sampel yang diambil dari populasi secara random. Analisis yang dilakukan untuk mengetahui tercapainya tujuan penelitian. Adapun analisis yang digunakan adalah analisis deskripsi data, dan analisis linier ganda.

\section{Hasil Penelitian dan Pembahasan}

Pengujian hipotesis dilakukan untuk mengetahui apakah hipotesis yang diungkapkan pada penelitian ini dapat diterima atau ditolak.

\section{Uji Hipotesis Pertama}

Hipotesis pertama dalam penelitian ini yang berbunyi "ada hubungan yang positif dan signifikan mutu guru dengan kinerja guru SD di Kecamatan Suralaga Kabupaten Lombok Timur". Sesuai dengan analisis regresi yang dilakukan dengan menggunakan program SPSS 16.0. yang hasil rangkuman analisis regresi linier dapat dilihat pada tabel berikut :

Tabel 5. Rangkuman Hasil Uji Analisis Hipotesis Pertama

\begin{tabular}{lcccc}
\hline Variabel & $\begin{array}{c}\text { Koefisien } \\
\mathbf{R}\end{array}$ & $\begin{array}{c}\text { Koefisien } \\
\mathbf{R}^{2}\end{array}$ & $\mathbf{f}{ }_{\text {-hit }}$ & Sig. \\
\hline $\begin{array}{l}\text { Mutu } \\
\text { Guru } \\
\left(X_{1}\right)\end{array}$ & 0.446 & 0.199 & 32.360 & 0.000 \\
\hline
\end{tabular}

$\left(\mathrm{X}_{1}\right)$

Sumber: data primer diolah

Hasil analisis yang diperoleh terhadap koefisien (R) sebesar 0.446 sedangkan koefisien $\left(R^{2}\right)$ sebesar 0.199. Bahwa besar hubungan variabel mutu guru $\left(\mathrm{X}_{1}\right)$ terhadap kinerja guru (Y) adalah sebesar 0.199. terdapat kontribusi variabel $\left(\mathrm{X}_{1}\right)$ terhadap variabel $(\mathrm{Y})$ sebesar $19.9 \%$. Artinya bahwa $19.9 \%$ kinerja guru ada hubungannya dengan mutu guru.

Dari hasil analisis diperoleh yang dipaparkan pada tabel di atas, dapat diketahui bahwa, nilai $\mathrm{F}_{\text {hitung }}$ sebesar 32.360 dengan signifikan sebesar $0.000(\mathrm{p}<0.05)$. Artinya bahwa nilai signifikansi kurang dari $0.05 \quad(0.000<$ 0.05) maka hipotesis dalam penelitian ini menyatakan Ho ditolak dan Ha diterima, yang artinya terdapat hubungan yang positif dan signifikan antara mutu guru dengan kinerja guru.

\section{Pengujian Hipotesis Kedua}

Dalam hipotesis yang kedua berbunyi "Ada hubungan yang positif dan signifikan kepemimpinan kepala sekolah dengan kinerja guru SD di se-Kecamatan Suralaga Kabupaten Lombok Timur". Sesuai dengan analisis regresi yang dilakukan dengan menggunakan program SPSS 16.0. yang hasil rangkuman analisis regresi linier dapat dilihat pada tabel berikut:

Tabel 6. Hasil Analisis Uji Hipotesis Kedua

\begin{tabular}{ccccc}
\hline Variabel & $\begin{array}{c}\text { Koefisien } \\
\mathbf{R}\end{array}$ & $\begin{array}{c}\text { Koefisien } \\
\mathbf{R}^{\mathbf{2}}\end{array}$ & $\mathbf{f}_{\text {-hit }}$ & Sig. \\
\hline$\left(\mathrm{X}_{2}\right)$ & 0.569 & 0.323 & 9.560 & 0.006 \\
\hline
\end{tabular}

Sumber: data primer diolah

Hasil analisis yang diperoleh terhadap koefisien $(\mathrm{R})$ sebesar 0.569 sedangkan koefisien $\left(\mathrm{R}^{2}\right)$ sebesar 0.323. Bahwa sumbangan variabel kepemimpinan kepala sekolah $\left(\mathrm{X}_{2}\right)$ terhadap kinerja guru (Y) adalah sebesar 0.323. Terdapat kontribusi variabel $\left(\mathrm{X}_{2}\right)$ terha- 
dap variabel (Y) sebesar 32.3\%. Artinya bahwa $32.3 \%$ kinerja guru ditentukan atau ada hubungannya dengan kepemimpinan kepala sekolah (bukti lampiran 12).

Berdasarkan hasil analisis yang diperoleh dari tabel di atas, dapat diketahui bahwa, nilai $\mathrm{F}_{\text {hitung }}$ sebesar 9.560 dengan signifikan sebesar $0.006(\mathrm{p}<0.05)$. Artinya bahwa $\mathrm{H}_{0}$ diterima untuk uji signifikansi konstanta, yang berarti konstanta tidak signifikan (nilai signifikannya $0.006<0.05$ ) yang artinya variabel independen $\mathrm{X}_{2}$ mempunyai hubungan yang positif dan signifikan dengan variabel dependen $\mathrm{Y}$. Maka hipotesis dalam penelitian ini menyatakan Ha diterima, yaitu terdapat hubungan yang positif dan signifikan antara kepemimpinan kepala sekolah dengan kinerja guru.

Pengujian Hipotesis Ketiga

Dalam hipotesis yang ketiga berbunyi "Ada hubungan yang positif dan signifikan status ekonomi (SE) dengan kinerja guru SD di se-Kecamatan Suralaga Kabupaten Lombok Timur". Sesuai dengan analisis regresi yang dilakukan dengan menggunakan program SPSS 16.0. yang hasil rangkuman analisis regresi linier dapat dilihat pada tabel berikut:

Tabel 7. Hasil Analisis Uji Hipotesis Ketiga

\begin{tabular}{ccccc}
\hline Variabel & $\begin{array}{c}\text { Koefisien } \\
\mathbf{R}\end{array}$ & $\begin{array}{c}\text { Koefisien } \\
\mathbf{R}^{\mathbf{2}}\end{array}$ & $\mathbf{f}{ }_{\text {hit }}$ & Sig. \\
\hline$\left(\mathrm{X}_{3}\right)$ & 0.214 & 0.046 & 6.253 & 0.014 \\
\hline
\end{tabular}

Sumber: data primer diolah

Hasil analisis yang diperoleh terhadap koefisien (r) sebesar 0.214 sedangkan koefisien $\left(\mathrm{r}^{2}\right)$ sebesar 0.046. Bahwa sumbangan variabel status sosial ekonomi (SE) guru $\left(\mathrm{X}_{3}\right)$ terhadap kinerja guru (Y) adalah sebesar 0.046. Artinya kontribusi variabel $\left(\mathrm{X}_{3}\right)$ terhadap variabel (Y) sebesar 4.6\%. Artinya bahwa $4.6 \%$ kinerja guru ditentukan atau ada hubung-annya dengan status ekonomi (SE) guru.

Berdasarkan hasil analisis yang diperoleh dari tabel di atas, dapat diketahui bahwa, nilai $F_{\text {hitung }}$ sebesar 6.253 dengan signifikan sebesar 0.014 ( $\mathrm{p}<0.05$ ). Artinya bahwa $\mathrm{H}_{0}$ diterima untuk uji signifikansi konstanta, yang berarti konstanta tidak signifikan (nilai signifikannya $0.014<0.05$ ) yang artinya variabel independen $\mathrm{X}_{3}$ mempunyai hubungan yang linier dengan variabel dependen Y. Maka hipotesis dalam penelitian ini menyatakan Ha diterima, yaitu terdapat hubungan yang positif dan signifikan antara status ekonomi (SE) guru dengan kinerja guru.

\section{Pengujian Hipotesis Keempat}

Sesuai dengan hasil analisis yang dilakukan, hipotesis keempat yang berbunyi "Ada hubungan positif dan signifikan mutu guru, kepemimpinan kepala sekolah dan SE yang dengan kinerja guru SD di Kecamatan Suralaga Kabupaten Lombok Timur." Pada pengujian hipotesis keempat ini, yang dianalisis dengan menggunakan program SPSS 16.0 yang hasil rangkuman analisis regresi linier dapat dilihat pada tabel berikut:

Tabel 8. Uji Hipotesis Keempat

\begin{tabular}{lcccc}
\hline Variabel & $\begin{array}{c}\text { Koefisien } \\
\mathbf{R}\end{array}$ & $\begin{array}{c}\text { Koefisien } \\
\mathbf{R}^{\mathbf{2}}\end{array}$ & $\mathbf{F}_{\text {hit }}$ & Sig \\
\hline $\begin{array}{l}\text { X1, X2 } \\
\text { X3 }\end{array}$ & 0.769 & 0.591 & 8.679 & 0.001 \\
\hline
\end{tabular}

Sumber: data primer diolah

Hasil analisis yang diperoleh bahwa koefisien (R) sebesar 0.769 sedangkan koefisien $\left(\mathrm{R}^{2}\right)$ sebesar 0.591. Bahwa sumbangan variabel mutu guru $\left(\mathrm{X}_{1}\right)$, kepemimpinan kepala sekolah $\left(\mathrm{X}_{2}\right)$ dan status ekonomi (SE) guru $\left(\mathrm{X}_{3}\right)$ secara bersama-sama terhadap kinerja guru (Y) sebesar 0.591. Artinya kontribusi variabel $\mathrm{X}_{1}, \mathrm{X}_{2}$ dan $\mathrm{X}_{3}$ terhadap variabel (Y) sebesar $59.1 \%$. Artinya bahwa $59.1 \%$ kinerja guru ditentukan atau ada hubungannya dengan mutu guru $\left(\mathrm{X}_{1}\right)$, kepemimpinan kepala sekolah $\left(\mathrm{X}_{2}\right)$ dan status ekonomi (SE) guru (bukti lampiran 14).

Berdasarkan hasil analisis yang diperoleh dari tabel di atas, dapat diketahui bahwa, nilai $F_{\text {hitung }}$ sebesar 8.679 dengan signifikan sebesar 0.001 ( $\mathrm{p}<0.05$ ). Artinya bahwa $\mathrm{H}_{0}$ diterima untuk uji signifikansi konstanta, yang berarti konstanta tidak signifikan (nilai signifikannya $0.001<0.05$ ) yang artinya variabel independen $\mathrm{X}_{1}, \mathrm{X}_{2}$, dan $\mathrm{X}_{3}$ mempunyai hubungan yang positif dengan variabel dependen Y. Maka hipotesis dalam penelitian ini menyatakan Ha diterima, yaitu terdapat hubungan yang positif dan signifikan antara mutu guru $\left(\mathrm{X}_{1}\right)$ kepemimpinan kepala sekolah $\left(\mathrm{X}_{2}\right)$ dan status ekonomi (SE) guru $\left(\mathrm{X}_{3}\right)$ dengan kinerja guru (Y).

Sesuai dengan analisis yang dilakukan, diperoleh nilai koefisien a sebesar 111.419 yang berarti jika semua variabel bebas memiliki nilai (0) nol, maka nilai variabel terikat sebesar 111.419; koefisien regresi $\mathrm{x}_{1}\left(\mathrm{~b}_{1}\right)$ sebesar 0.731; koefisien regresi $\mathrm{x}_{2}\left(\mathrm{~b}_{2}\right)$ sebesar -1.157; koefisien regresi $\mathrm{x}_{3}\left(\mathrm{~b}_{3}\right)$ sebesar -0.149 ; sehingga model persamaan regresinya sebagai 
berikut: $\mathrm{Y}=111.419+0.731 \mathrm{x}_{1}-1.157 \mathrm{x}_{2}-$ $0.149 \mathrm{x}_{3}$

Nilai koefisien a atau nilai konstanta sebesar 115.212 menunjukan bahwa jika variabel bebas mutu guru $\left(\mathrm{x}_{1}\right)$, kepemimpinan kepala sekolah $\left(\mathrm{x}_{2}\right)$, dan status ekonomi guru $\left(\mathrm{x}_{3}\right)$ mempunyai nilai nol (0), maka variabel terikat kinerja guru $(\mathrm{Y})$ akan mempunyai nilai tetap yaitu 111.419. Nilai koefisien mutu guru $\left(\mathrm{x}_{1}\right)$ sebesar 0.731 yang mempunyai arti bahwa setiap kenaikan nilai mutu guru satu satuan maka variabel terikat kinerja guru (Y) akan naik sebesar 0.731 dengan beranggapan bahwa variabel bebas yang lain tetap. Nilai koefisien kepemimpinan kepala sekolah (x2) sebesar -1.157 yang maknanya setiap penurunan nilai kepemimpinan kepala sekolah satu satuan maka variabel terikat kinerja guru (Y) akan turun sebesar -1.157 dengan asumsi bahwa nilai variabel bebas yang lain tetap. Nilai koefisien status ekonomi (SE) guru sebesar -0.149 yang maknanya bahwa setiap penurunan nilai SE guru satu satuan, maka nilai variabel terikat kinerja guru (Y) akan turun sebesar -0.149 dengan anggapan bahwa nilai variabel bebas yang lain tetap.

\section{Pembahasan}

Hubungan Mutu Guru dengan Kinerja Guru

Untuk meningkatkan mutu guru hal yang tidak bisa dilupakan adalah kualifikasi akademik, kompetensi, dan sertifikasi pendidik

Dalam meningkatkan kinerja guru, hal utama yang harus dibenahi adalah mutu guru itu sendiri. Indikator yang digunakan untuk melihat mutu guru adalah kualifikasi akademik, kompetensi guru, dan setifikasi guru. Hal ini tercermin dalam UU pasal 8 yang mengatakan "Guru wajib memiliki kualifikasi akademik, kompetensi, sertifikat pendidik, sehat jasmani dan rohani, serta memiliki kemampuan untuk mewujudkan tujuan pendidikan nasional". Di Kabupaten Lombok Timur, guru yang memiliki kualifikasi S-1 cukup banyak, terlihat dari seluruh responden $70.13 \%$ guru yang sudah memiliki kualifikasi ijazah minimal sesuai dengan yang diamanatkan dalam undang-undang guru dan dosen. Ini menandakan bahwa dalam meningkatkan kinerja guru di Kabupaten Lombok Timur memiliki peluang yang sangat besar.

Kompetensi adalah pengetahuan, keterampilan dan kemampuan yang dikuasai oleh seorang yang telah menjadi bagian dari diri- nya, sehingga ia dapat melakukan perilakuperilaku kognitif, afektif, dan psikomotirik dengan sebaik-baiknya. Kompetensi yang harus dimiliki oleh setiap pendidik adalah kompetensi pedagogik, kompetensi keperibadian, kompetensi profesional dan kompetensi sosial.

Sertifikasi pendidik dimaksudkan untuk meningkatkan kemapuan seorang guru dalam melaksanakan tugasnya yaitu mendidik. Sertifikat dapat dimaknai sebagai tanda pencapaian kompetensi akhir pendidik dinyatakan dalam dokumen ijazah dan atau sertifikat kompetensi. Adapun tujuan dari Sertifikasi guru yaitu untuk: (1) menentukan kelayakan guru dalam melaksanakan tugas sebagai agen pembelajaran dan mewujudkan tujuan pendidikan nasional, (2) meningkatkan proses dan mutu hasil pendidikan, (3) meningkatkan martabat guru, (4) meningkatkan profesionalitas guru, (5) meningkatkan kesejahteraan guru.

Dengan kualifikasi akademik yang dimiliki oleh guru diharapkan untuk meningkatkan kinerja mereka dalam mendidik siswa di sekolah, begitu halnya dengan kompetensi yang disyaratkan agar guru dapat membuat pembelajaran bervariasi dan menggunakan/ memanfaatkan metode dan alat peraga dengan maksimal, dan dengan sertifikasi pendidik guru dapat meningkatkan kinerjanya dengan baik.

\section{Hubungan Kepemimpinan Kepala Sekolah dengan Kinerja Guru}

Kepemimpinan kepala sekolah merupakan hal yang tidak bisa dianggap sepele dalam meningkatkan kinerja guru. kepemimpinan yang baik merupakan pendongkrak kinerja bawahannya. Hal ini yang ungkapkan oleh (Steve Munby, 2009, p.40) yang maksudnya adalah kepala sekolah hendaknya meningkatkan standar agar mereka diikuti oleh bawahan mereka. Kepala sekolah dikatakan berhasil dalam meningkatkan kinerja bawahannya apabila kepala sekolah memahami keberadaan sekolahannya dan memiliki kemampuan untuk melaksanakan tugas dan perannya dalam membina guru/ karyawan, baik sebagai educator, manager, administrator, supervaisor, leader, inovator dan motivator.

Untuk mewujudkan hal itu (meningkatkan kinerja para guru untuk mendidik siswa), dibutuhkan kepala sekolah yang memiliki talenta, kepala yang memiliki kualifikasi dan standar kompetensi untuk menjadi kepala se- 
kolah dikutip dari (Muchtar dan Iskandar, 2009, pp.92-94) adalah:

\section{Standar Kualifikasi Kepala Sekolah}

Standar kualifikasi kepala sekolah yaitu; Kualifikasi umum dan Kualifikasi khusus

\section{Standar Kompetensi Kepala Sekolah}

Standar kompetensi kepala sekolah yaitu; 1) Kompetensi keperibadian; 2) Kompetensi manajerial; 3) Kompetensi kewirausahaan; 4) Kompetensi supervisi, dan 5) Kompetensi sosial

Dengan demikian, kehadiran kepala sekolah ditengah-tengah guru, dengan gaya kepemimpinan yang baik merupakan sumbangan yang sangat baik terhadap kinerja guru.

Hubungan Status Ekonomi (SE) dengan Kinerja Guru

SE guru mempunyai kontribusi yang positif terhadap kinerja guru. Hal ini sangat erat kaitannya dengan kondisi dinamika ekonomi guru di rumah selain kesejahteraan guru di sekolah. Kondisi dinamika tersebut dikenal dengan ketahanan keluarga. Hak ini sesuai dengan UU No. 10 tahun 1992 (pasal 1 ayat 15) yaitu " Kondisi dinamika suatu keluarga yang memiliki keuletan dan ketangguhan serta mengandung kemampuan fisik-material dan psikis mental spiritual guna hidup mandiri dan mengembangkan diri dan keluarga untuk hidup harmoni dalam meningkatkan kesejahteraan lahir dan batin".

Faktor status ekonomi sangat berpengaruh terhadap kelangsungan kinerja seseorang dalam bekerja apalagi kinerja guru di sekolah. Semakin sejahtera seseorang/kebutuhan hidup sehari-hari seseorang terpenuhi maka akan sangat mengukur kinerjanya. Begitu halnya dengan guru di sekolah, apabila kebutuhan seorang guru (guru sejahtera) maka bisa dipastikan guru akan termotivasi dalam bekerja untuk mendidik siswa. Seperti yang dikemukakan oleh Eggen \& Kauchak yang di kutip dari Basilius (2008, p.423) dalam penelitiannya mengatakan bahwa ststus sosial ekonomi merupakan salah satu dari sekian banyak faktor yang paling berpengaruh terhadap kinerja sekolah (guru). Diharapkan dengan menyejahterakan guru maka akan sangat meningkatkan kinerjanya sehingga bisa meningkatkan output sekolah untuk menyongsong masa depan yang lebih baik.
Hubungan Mutu Guru, Kepemimpinan Kepala Sekolah dan Status Ekonomi (SE) dengan Kinerja Guru

Dari hasil analisi di atas menggambarkan bahwa mutu guru mempunyai kontribusi yang sangat efektif dalam meningkatkan kinerja guru di sekolah. Kinerja guru yang dimaksud adalah kualitas kinerja guru dalam mempersiapkan generasi muda/siswa untuk menghadapi dunia global. Kualitas kinerja guru dapat dinyatakan dalam Peraturan Menteri Pendidikan Nasional Republik Indonesia No. 16 Tahun 2007 tentang standar kualifikasi akademik dan kompetensi guru. Dijelaskan bahwa standar kompetensi guru dikembangkan secara utuh dari empat kompetensi utama yaitu kompetensi pedagogik, kompetensi kepribadian, kompetensi sosial, dan kompetensi profesional.

Hasil analisis menggambarkan bahwa keberadaan kepala sekolah/kepemimpinan kepala sekolah merupakan tolok ukur dari kinerja guru dalam meanjalankan tugasnya. Kepala sekolah memegang peranan yang sangat penting dalam dunia pendidikan lebih-lebih dalam mendongkrak kinerja guru. Untuk meningkatkan kinerja guru, dibutuhkan pemimpin/kepala sekolah yang ideal. Pemimpin yang ideal adalah pemimpin yang mampu merencanakan kegiatan sekolah dengan sebaik-baiknya, memotivasi bawahannya untuk bekerja semaksimal mungkin untuk mengasilkan output yang handal dan mengevaluasi kinerja bawahannya. Hal ini sesuai yang diungkapkan oleh John Adair (2006, pp.13-14) adalah kepala sekolah berfungsi meliputi: (Planning) merencanakan, (Initiating) pemicu, (Controlling) mengontrol, (Supporting) mensuport, (Informing) memberi informasi, (Evaluating) mengevaluasi.

Kinerja guru tidak hanya didukung oleh kepemimpinan kepala sekolah akan tetapi kinerja guru didukung oleh tingkat penguasaan guru terhadap materi ajar (kompetensi), kualifikasi guru dan ststus ekonomi guru. Kualifikasi dan kompetensi yang dimaksud sebagaimana yang disinggung pada UU guru dan dosen pasal 8 dan 10 tahun 2005 adalah kualifikasi minimal S-1/D-IV, sedangkan kompetensi secara umum yang harus dimiliki oleh setiap guru adalah kompetensi padagogik, kompetensi keperibadian, kompetensi sosial, dan kompetensi profesional.

Hal yang tidak bisa dilupakan untuk meningkatkan kinerja guru adalah ekonomi guru dan kesejahteraannya. Dalam UU no 14 
tahun 2005 pasal 14 ayat 1 huruf a menyatakan bahwa guru berhak memperoleh penghasilan di atas kebutuhan hidup minimum dan jaminan kesejahteraan sosial. Pasal di atas menerangkan bahwa dalam melaksanakan keprofesionalannya untuk meningkatkan kinerjanya guru berhak menerima pengasilan dan kesejahteraan. Dengan menyejahterakan guru diharapkan kinerja guru akan meningkat. Guru diyakini sebagai komponen terpenting dalam seluruh komponen pembelajaran karena guru mampu menggerakkan output pembelajaran dengan meningkatkan kinerjanya. Untuk meningkatkan kinerja guru, maka semua kalangan harus meningkatkan SDM guru. Pemberdayaan sumber daya manusia hanya mempunyai arti apabila diarahkan pada upaya untuk mewujudkan pembangunan ekonomi guru. Jika keuangan rumah tangga guru tidak terpenuhi maka guru tidak akan bisa meningkatkan kinerjanya dengan optimal.

\section{Simpulan dan Saran}

Simpulan

Mutu guru di Kecamatan Suralaga memiliki hubungan yang positif dan signifikan terhadap kinerja guru. Hal ini dapat dilihat pada nilai $\mathrm{F}_{\text {hitung }}$ sebesar 32.360 dengan signifikansi $0.000(\mathrm{p}<0,05)$ yang artinya ada hubungan yang erat antara mutu guru dengan kinerja guru. Keeratan hubungan mutu guru dengan kinerja guru di Kecamatan Suralaga dapat dilihat dengan besarnya nilai $\mathrm{R}^{2}$ sebesar $19.9 \%$. Yang artinya $19.9 \%$ kinerja guru ada hubungannya dengan mutu guru.

Dari hasil analisis yang dilakukan pada uji hipotesis kedua, diperoleh nilai $\mathrm{F}_{\text {hitung }}$ 9.560 dengan signifikansi sebesar 0.006 ( $p<$ 0.05 ) hipotesis diterima yang artinya kepemimpinan kepala sekolah mempunyai hubungan erat dengan kinerja guru di Kecamatan Suralaga. Hubungan ini dapat dilihat dengan besarnya nilai $\mathrm{R}^{2}$ sebesar $32.3 \%$. 32.3\% kinerja guru ada hubungannya dengan kinerja guru.

Dari hasil analisis pada uji hipotesis ketiga diperoleh nilai $\mathrm{F}_{\text {hitung }} 6.253$ dengan signifikansi 0.014 ( $p<0.05$ ) hipotesis diterima yang artinya bahwa SE guru mempunyai hubungan yang erat dengan kinerja guru. Keeratan SE dengan kinerja guru dapat dilihat dari nilai $\mathrm{R}^{2}$ sebesar $4.3 \%$. $4.3 \%$ kinerja guru ada hubungannya dengan kinerja guru.

Dari hasil uji hipotesis keempat diperolah nilai $F_{\text {hitung }} 8.679$ dengan signifikansi se- besar $0.001(\mathrm{p}<0.05)$ hipotesis diterima yang artinya mutu guru, kepemimpinan kepala sekolah dan SE guru ada hubungannya dengan kinerja guru. Hubungan ini dapat dilihat pada nilai $\mathrm{R}^{2}$ sebesar $59.1 \%$. Artinya $59.1 \%$ kinerja guru ada hubungannya dengan mutu guru, kepemimpinan kepala sekolah, dan SE guru.

Saran

Mengingat akan pentingnya kinerja guru dalam mendidik siswa di sekolah, diharapkan kepada pemerintah pusat, pemerintah daerah, dan dinas pendidikan agar memberikan kesempatan kepada para guru untuk meningkatkan kualifikasinya sesuai dengan undangundang guru dan dosen No.14 tahun 2005 yang menuntut guru untuk memiliki kualifikasi akademik minimal S-1.

Disarankan kepada pemerintah, dinas, dan yayasan agar memperhatikan kesejahteraan guna untuk meningkatkan kinerja guru dalam mendidik, membimbing, dan mengajar siswa di sekolah maupun di masyarakat.

Untuk meningkatkan kinerjanya, guru hendaknya meningkatkan mutu dengan meningkatkan kompetensi dan sertifikasi melalui penelitian tindakan kelas, pelatihan-pelatihan, seminar dan workshop sesuai dengan bidangnya.

Untuk meningkatkan kinerja guru di Kecamatan Suralaga Kabupaten Lombok Timur, diharapkan kepada kepala sekolah dan dinas terkait untuk lebih tanggap dalam memenuhi kebutuhan guru baik kebutuhan akan pengayaan, pelatihan, dan pendampingan.

\section{Daftar Pustaka}

Aider. J. (2006). Leadership \& motivation:the fifty-fifty rule \& and eight Key principles Of motivating others. London and Philadelphia: Kogan Page

Asmani, J. M. (2009). Manajemen pengelolaan kepemimpinan pendidikan profesional, panduan quality control bagi para pelaku lembaga pendidikan. Yogyakarta: DIVA Press

Harsono \& Susilo, Joko. (2010). Pemberontakan Guru: menuju peningkatan kualitas. Yogyakarta : Pustaka Pelajar

Muchtar \& Iskandar. (2009). Orientasi baru supervisi pendidikan. Jakarta: Gaung Persada Press. 
Munby, S. (2009). School leadership today. England: National College Publishing.

Rivai, V. \& Murni, S. (2012). Education Management. Jakarta: PT RajaGrafindo persada
Sudjana, D.. (2006). Peran lembaga pendidik tenaga kependidikan dalam mengembangkan kualitas pendidik dan tenaga kependidikan. Universitas Negeri Jakarta: Jurnal Ilmiah Visi Pendidik dan tenaga pendidikan non formal. ISSN 1907-9176. Vol 1, no. 22006. 